5. Бенин В. Л. Учебное пособие по теории и практики управления. - 2007. - № 5. - С. 30социальной философии. / В. Л.Бенин, М. В. 42. Десяткина. - Уфа: БГПУ, 1997. - 86 с.

6. Клейнер, Г. Системный подход к экономической политике / Г. Клейнер // Проблемы

7. Ходжсон Дж. Социально-экономические последствия прогресса знаний и нарастания сложности / Дж.Ходжсон // Вопросы экономики. 2001.- №8.

Експерт редакційної колегії к.е.н., доцент УкрДУЗТ Токмакова І.В.

УДК $658.7: 656.2$

\title{
ФОРМУВАННЯ СТРУКТУРИ ТРАНСПОРТНО-ЛОГІСТИЧОГО КЛАСТЕРА У ТРАНСКОРДОННОМУ СПІВРОБІТНИЦТВІ
}

\author{
Озерська Г.В., к.е.н., доцент (ХНУРЕ)
}

У статті запропоновано структуру транспортно-логістичного кластеру у транскордонному співробітництві у контексті регіонального розвитку. Автором визначено, щзо регіональний транспортнологістичний кластер у транскордонному співробітництві матиме дворівневу структура. Зокрема, перший рівень - внутрішній - запропоновано будувати за рахунок споживчого ринку регіону, а саме підприємств промисловості, транспорту, торгівлі тощо, організащій та населення регіону, а також елементів $і$ ланок транспортно-логістичного кластеру. Другий рівень - зовнішній - формується за рахунок аналогічних об’єктів різних регіонів України, країн СНД і далекого зарубіжжя. Автором зазначено, щзо в умовах реалізації транскордонного співробітництва створення цे інтеграція регіональних транспортнологістичних кластерів є одним з першочергових інструментів реалізачії державної регіональної політики, щзо спрямована на підвищення рівня життя громадян прикордонних територій, забезпечення конкурентоспроможності господарського комплексу, впровадження інноваційно-інвестиційної моделі розвитку, гармонізацію нормативно-правових і сочіально-економічних умов розвитку промислового та сільськогосподарського виробництв, кооперачії, науково-технічного й інших видів прикордонної взаємодї, особливо у сфері бізнесу, надання послуг і трансферту технологій.

Ключові слова: транспортно-логістичний кластер, регіональний розвиток, транскордонне співробітництво, структура транспортно-логістичного кластеру, рівні структури транспортнологістичного кластеру.

\section{ФОРМИРОВАНИЕ СТРУКТУРЫ ТРАНСПОРТНО-ЛОГІСТИЧОГО КЛАСТЕРА В ТРАНСГРАНИЧНОМ СОТРУДНИЧЕСТВЕ}

\author{
Озерская А.В., к.э.н., доцент (ХНУРЭ)
}

В статье предложена структура транспортно-логистического кластера в трансграничном сотрудничестве в контексте регионального развития. Автором определено, что региональный транспортно-логистический кластер в трансграничном сотрудничестве будет иметь двухуровневую структуру. В частности, первый уровень - внутренний - предложено строить за счет потребительского рынка региона, а именно предприятий промышленности, транспорта, торговли, организаций и населения региона, а также элементов и звеньев транспортно-логистического кластера. Второй уровень внешний- формируется за счет аналогичных объектов различных регионов Украины, стран СНГ и дальнего зарубежья. Автором отмечено, что в условиях реализации трансграничного сотрудничества создание и интеграция региональных транспортно-логистических кластеров является одним из первоочередных инструментов реализаџии государственной региональной политики, направленной на повышение уровня жизни граждан приграничных территорий, обеспечение конкурентоспособности хозяйственного комплекса, внедрение инновационно-инвестиционной модели развития, гармонизацию нормативно-правовых и соџиально-экономических условий развития промышленного $и$ сельскохозяйственного производств, кооперации, научно-технического и других видов приграничного взаимодействия, особенно в сфере бизнеса, предоставления услуг и трансферта технологий.

Ключевые слова: транспортно-логистический кластер, региональное развитие, 
трансграничное сотрудничество, структура транспортно-логистического кластера, уровне структуры транспортно-логистического кластера.

\title{
THE FORMATION OF THE STRUCTURE OF THE TRANSPORT LOGSTICS CLUSTER IN CROSS-BORDER COOPERATION
}

\author{
Ozersky A.V., Ph.D., associate Professor (KNURE)
}

In the article the structure of transport and logistics cluster in the cross-border cooperation in the context of regional development. The author determined that the regional transport and logistics cluster in the cross-border cooperation will be a two-level structure. In particular, the first level is internal is proposed to build at the expense of the consumer market of the region, namely industry, transport, Commerce, organizations and population of the region, as well as the elements and links in the transportation and logistics cluster. The second level is external-is formed by similar facilities in various regions of Ukraine, CIS and far abroad. The author noted that in the implementation of cross-border cooperation, the establishment and integration of regional transport and logistics cluster is one of the primary tools of implementation of the state regional policy aimed at improving the lives of citizens of border areas, ensure the competitiveness of the economic system, the introduction of innovativeinvestment model of development, and harmonization of regulatory and socio-economic conditions for the development of industrial and agricultural enterprises, cooperatives, scientific-technical and other types of crossborder cooperation, particularly in the field of business, services and technology transfer.

Keywords: transport and logistics cluster, regional development, cross-border cooperation, the structure of the transport and logistics cluster, the level structure of the transport and logistics cluster.

Постановка проблеми та їі зв'язок 3 науковими чи практичними завданнями. Світові інтеграційні процеси постійно спонукають до формування та розвитку сучасних транспортнологістичних систем за напрямками руху транснаціональних транспортних потоків, а саме у забезпеченні транскордонного співробітництва. Посилаючись на досвід розвинутих країн використання логістичних систем в якості ефективного інструменту планування, організації та управління рухом матеріального потоку та потоків, що його супроводжують, дозволяе зменшити загальні логістичні витрати на $12-35 \%$, транспортні витрати на 7-20\%, витрати на навантажувальнорозвантажувальні роботи i збереження матеріального потоку на $20-30 \%$, прискорити швидкість обігу матеріальних ресурсів на 20-40\%. Тому, в якості важливого фактору економічного росту країн та регіонів в світовій практиці набув процес формування різнопрофільної та багатофункціональної інтегрованої транспортнологістичної системи починаючи 3 місцевих та регіональних рівнів 3 послідуючою інтеграцією в транснаціональні системи. Ефективним інструментом в цьому процесі, посилаючись на досвід країн з успішною економікою, $є$ розвиток на основі кластерної моделі, як фактору підвищення регіональної конкурентоспроможності

транскордонному співробітництві.

Аналіз досліджень і публікацій останніх років. Кластерні моделі економічного розвитку стали об'єктами аналізу низки українських i російських вчених: С.І. Соколенка [8,9], Я.Б. Олійника [1], Ю.О. Ніколаєва [7] та ін. Проблеми розвитку інфраструктури транскордонного співробітництва

та

підвищення

конкурентноздатності транспортно-логістичних систем в економічній літературі набули певного висвітлення в контексті досліджень формування передумов активізації економічної інтеграції України у світове господарство. Зокрема, актуальним $є$ дослідження багатьох вчених, а саме: Данько М.I., Диканя В.Л., Якименко Н.В. [2], Ейтутіса Д. [3], Леонт'єва Р., Соболева А. [5], Лисака I. [6], Устенко М. [10], Ларіної Р.P. [4] та ін.

Виділення невирішених раніше частин загальної проблеми. Попри беззаперечні досягнення вчених, науковий аналіз міжнародних відносин транскордонного економічного співробітництва в ракурсі формування транспортнологістичних кластерів ще грунтовно не розроблено, бракує наукових розробок 3 питань методології формування транспортно-логістичних кластерів. Частковому вирішенню цієї проблеми присвячено дослідження, викладене у статті.

Формування цілей статті. Саме тому основною метою статті $\epsilon$ визначення структури транспортно-логістичного кластеру у транскордонному співробітництві.

Виклад основного матеріалу дослідження. Транскордонне співробітництво являє собою спільні дії, спрямовані на встановлення і поглиблення економічних, соціальних, науково-технічних, екологічних, культурних та інших відносин між територіальними громадами, їх представницькими органами, місцевими органами виконавчої влади України та територіальними громадами, відповідними органами влади інших держав у межах компетенції, визначеної їх національним 
законодавством.

Діяльність держав у напрямку транскордонного співробітництва визначається Європейською рамковою конвенцією про транскордонне співробітництво між територіальними громадами або владою, що прийнята 21 травня 1980 року у Мадриді та набула чинності з 22 грудня 1993 року.

Транскордонне співробітництво здійснюється у таких напрямках.

1. Традиційні угоди між адміністративнотериторіальними одиницями України й інших країн щодо співробітництва у сферах, які відносяться до їх компетенції (культура, гуманітарні зв'язки, спорт, освіта, екологія, тощо). Особливе місце у цьому ряду займають угоди про встановлення побратимських зв'язків. На сьогодні більш, ніж 50 міст України мають побратимські відносини 3 більш, ніж 160 адміністративно-територіальними одиницями зарубіжних країни (зокрема, Одеса - 25 міст-побратимів, Харків - близько 20, Дніпропетровськ - 15, Київ - більше 70, тощо).

2. Єврорегіони. На даний час прикордонні області нашої країни беруть участь у функціонуванні восьми єврорегіонів - це «Буг», «Карпатський», «Нижній Дунай», «Верхній Прут», «Дніпро», «Ярославна», «Донбас» і «Слобожанщина». До їх складу входять Волинська, Донецька, Закарпатська, Івано-Франківська, Луганська, Львівська, Одеська, Сумська, Чернівецька, Чернігівська та Харківська області України.

3.

Програми

прикордонного

співробітництва, що реалізуються в рамках Європейської політики сусідства Європейського Союзу. Україна приймає участь в чотирьох таких програмах: «Україна-Польща-Білорусь», «УкраїнаСловаччина-Угорщина-Румунія», «УкраїнаРумунія-Молдова» та «Чорне море» (програма, в якій приймає участь 10 країн Чорноморського регіону). Бюджет, який виділяє Свропейський Союз для реалізації цих програм, складає більше 378 млн. євро на 2013 рік. У рамках реалізації зазначених програм реалізуються проекти по таким напрямкам, як покращення управління кордонами, контакти між людьми, екологія, підвищення конкурентоспроможності прикордонних територій, тощо.

Розвиток транскордонного співробітництва для України надає ряд переваг.

По-перше, покращення стандартів управління. Шляхом застосування європейських норм і стандартів, а також використання кращих європейських практик можливо досягти значного підвищення якості управління на рівні регіонів.

По-друге, покращення інфраструктури. На кордонах України будуються мости, реконструюються прикордонні переходи на кошти Євросоюзу. У рамках діяльності єврорегіонів виділяються значні кошти на ремонт шкіл, фельдшерських пунктів, забезпечення комп'ютерною технікою, тощо.

По-третє, постійне спілкування між людьми, що сприяє кращому розумінню один одного та впливає на державну політику тієї чи іншої держави по відношенню до України.

Прийняті Європою «Маніфест кластеризації ЄС» (Брюссель, 2007), «Свропейський кластерний меморандум» (Стокгольм, 2008) визначають сьогодні стратегію розвитку європейського і світового співтовариства, включаючи країни СврАзЕС і базуються на розвитку кластерної політики регіонів, що формується за рахунок ефективної діяльності суб'єктів господарювання відповідних областей, включаючи транспортнологістичний сектор, який їх обслуговує.

На нашу думку, транспортно-логістичний кластер у транскордонному співробітництві матиме дворівневу структуру.

Перший рівень - внутрішній, а саме споживчий ринок регіону, представлений підприємствами промисловості, транспорту, торгівлі тощо, організаціями та населенням регіону, а також елементи і ланки ТЛК:

- підприємства всіх видів транспорту;

- підприємства промисловості, будівництва, сільського господарства, торгівлі;

- установи галузевої науки та ВНЗ, учбові центри;

- комплекси та термінали залізничного, повітряного і автомобільного транспорту;

- центри сервісу;

- регіональні розподільчі центри (розподільчі центри промислових підприємств, оптові бази і центри оптової торгівлі, центри дистрибуції, логістичні транспортно-розподільчі центри і термінальні комплекси);

- логістичні посередники - експедитори, перевізники, оптові торгові посередники, дистриб'ютори, власники терміналів і великих торгових складів, інформаційні та консалтинговоаналітичні компанії тощо;

- ринкова інфраструктура;

- об'єкти допоміжної інфраструктури;

- консалтингові компанії, девелопери, фінансові та інвестиційні компанії і установи, зацікавлені у розвитку об'єктів транспортнологістичного сектору регіону, страхові компаніі;

- структури та організації, що зацікавлені у налагодженні більш вигідних транспортних зв'язків, у пошуках нових ринків для своєї продукції;

- власники складів, вільних територій для вибору місць розміщенні термінального комплексу;

- об'єкти, що входять до складу транспортної інфраструктури регіону;

- власники автомобільних компаній, що готові працювати над новою технологією за участю залізниці та авіа транспорту тощо 
Другий рівень - зовнішній, а саме:

- підприємства промисловості, будівництва, сільського господарства, торгівлі різних регіонів України, країн СНД і далекого зарубіжжя, які беруть участь у міжрегіональному та міжнародному товарообміні з регіоном створення транспортнологістичного кластеру;

- транспортні, транспортно-експедиційні підприємства, логістичні посередники різних регіонів України, СНД і далекого зарубіжжя, компанії, які беруть участь у організації та забезпечення просування транспортних потоків регіонального транспортного вузла.

Висновки даного дослідження та перспективи подалыших робіт у цьому напрямку. У цілому створення й інтеграція регіональних транспортно-логістичних кластерів 3 точки зору реалізації транскордонного співробітництва $\epsilon$ одним 3 першочергових інструментів реалізації державної регіональної політики, що спрямована на підвищення рівня життя громадян прикордонних територій, забезпечення конкурентоспроможності господарського комплексу, впровадження інноваційно-інвестиційної моделі розвитку, гармонізацію нормативно-правових і соціальноекономічних умов розвитку промислового та сільськогосподарського виробництв, кооперації, науково-технічного й інших видів прикордонної взаємодії, особливо у сфері бізнесу, надання послуг і трансферту технологій.

\section{СПИСОК ЛІТЕРАТУРИ}

1 Географія світового господарства (3 основами економіки) [Текст]: навч. посіб. / Я.Б. Олійник та ін. [за ред. Я.Б. Олійника, І.Г. Смирнова]. - К.: Знання, 2011. - 640 с.

2 Данько M.I. Забезпечення конкурентоспроможності промислових підприємств України в умовах міжнародних транспортних коридорів [Текст]: монографія / М.І. Данько, В.Л. Дикань, Н.В. Якименко. - Харків: УкрДАЗТ, 2008. $170 \mathrm{c}$.

3 Ейтутіс Д.Г. Конкурентоспроможність регіональної залізниці [Текст]/ Д. Г. Ейтутіс // Залізничний транспорт України. - 2007. - №3. - С. 90-92.

4 Ларіна Р.Р. Формування та забезпечення надійності регіональних логістичних систем [Текст]: монографія / Р.Р. Ларіна. - Донецьк: «Норд-Пресс», 2005. $-284 \mathrm{c}$.

5 Леонтьев Р.Г. Инструменты определения конкурентоспособности видов транспорта [Текст] / Р.Г. Леонтьев, Н.Н. Лаптев, А.Н. Соболев // Бюллетень транспортной информации. - 2007. №2. - C. 6-17.

6 Лисак I. Чинники конкуренції транспортної галузі [Текст] / І. Лисак // Збірник наукових праць КУЕТТ. Серія «Економіка i управління». - 2004. - Вип. 6. - С. 218-223.

7 Ніколаєв Ю.О. Структура транспортнологістичного кластера та процес його формування [Текст] / Ю.О. Ніколаєв // Вісник соціальноекономічних досліджень. - 2012. - Вип. 1(44). - С. 345-350.

8 Соколенко C.I. Кластери в глобальній економіці / С.I. Соколенко. - Київ: Логос, 2004. $848 \mathrm{c}$.

9 Соколенко С.I. Розвиток економіки регіонів на основі інноваційних кластерів [Текст] / C.I. Соколенко // Інвестиційно-інноваційний розвиток економіки регіону: мат. IV з'їду Спілки економістів України та Міжн. наук.-практ. конф. [під заг. ред. В.В. Оскольського]. - К.: Навчальна книга. - Богдан, 2010. - С. 100-116.

10 Устенко М.О. Формування вітчизняних логістичних систем в умовах євроінтеграції [Текст] / М.О. Устенко // Вісник економіки транспорту i промисловості. - Харків: УкрДАЗТ, 2008. - С. 287289.

Рецензент д.е.н., професор УкрДУЗТ Компанієиь В.В. Експерт редакційної колегії к.е.н., дочент УкрДУЗТ Слагін Ю.В.

УДК 336.22

\title{
ПОДАТКОВІ НОВАЦІї 2015 РОКУ
}

\author{
Поколодний В.В., к.е.н.,доцент, \\ Поколодна О.В., к.н.д.у., доцент, \\ Камаєва Я.В., студентка (УкрДУЗТ)
}

Розглянуто основні новації оподаткування, щзо введені в дію з 01 січня 2015 року, в частині визначення та адміністрування податків, їх нарахування $і$ сплати. Змінами, внесеними до податкового законодавства, передбачено скорочення кількості податків та зборів з 22 до 9. Розрахунок податку на прибуток передбачено здійснювати на підставі даних бухгалтерського обліку. Збільшено межу для

(C) Поколодний В.В.,

Поколодна О.В.,

Вісник економіки транспорту і промисловості № 50, 2015

Камаєва Я.В. 